\title{
Funding defamation litigation
}

\author{
PAul Tweed
}

Senior Partner, Johnsons Solicitors (Belfast, Dublin and London)

\section{Current position in Northern Ireland}

$\mathrm{U}$ nlike in England, in this jurisdiction a plaintiff in a defamation action cannot avail of a conditional fee arrangement $(\mathrm{CFA})^{1}$ nor can he or she recover any after the event (ATE) insurance premium. While the position is likely to change in England in the near future (see below), nonetheless, with no entitlement to legal aid, libel litigants in Northern Ireland face significantly greater financial hurdles than their fellow UK citizens taking legal proceedings in London.

The Access to Justice (NI) Order 2003 Part III $^{2}$ does make provision for the introduction of CFAs and other litigation funding agreements in Northern Ireland. However, this part of the 2003 Order has not yet been brought into force. As a consequence, a plaintiff litigating in Northern Ireland is deprived of those options available to claimants in England and Wales.

Unfortunately, notwithstanding various representations I have made to the Legal Services Commission (LSC) and the judiciary, this unsatisfactory situation is unlikely to change in the foreseeable future without specific statutory intervention.

\section{Fee structure in England/Wales}

At the present time, a solicitor is entitled to offer a client the benefit of a CFA, with a potential mark up of up to 100 per cent, which is ultimately recoverable from an unsuccessful defendant. Furthermore, a plaintiff can recover, in addition to any damages awarded, the ATE premium, subject to compliance with certain notice requirements. While the availability of this type of CFA is very much dependent on a firm of media lawyers being prepared to take on a particular case, nonetheless the attraction of a success fee has tended to make any reciprocal financial risk worthwhile.

The recovery of success fees has also facilitated claimant solicitors in pursuing a broader range of potential claims, including those with more questionable merit and this has been the subject of recent debate. It has been suggested that this has led to a chill factor for defendants in contesting claims, as cases become frontloaded with significant costs from the outset. However, successful defendants are still entitled to recover party costs from

1 Access to Justice Act 1999, s. 27.

22003 No 435 (NI 10). 
plaintiffs, which may be covered by ATE insurers. Plaintiffs are not liable to their own solicitors under CFAs for cases that are unsuccessful and it has been suggested that this has fuelled a claims culture. On the other hand, these measures have made the availability of legal remedies more accessible for claimants with more limited financial means, particularly when considering pursuit of defendants with substantial financial resources, such as a wellestablished nationwide publisher with both in-house and external legal representation.

The campaign for reform of CFAs has received momentum from the decision of the European Court of Human Rights (ECtHR) in Mirror Group Newspapers Ltd v UK. ${ }^{3}$ Mirror Group Newspapers (MGN) sought to challenge the House of Lords' decision in Campbell v MGN Ltd ${ }^{4}$ on the basis that the award of costs to the claimant, including success fees, constituted a disproportionate interference with MGN's Article 10 rights. $^{5}$

The ECtHR agreed with the applicant's submission that the requirement to pay success fees constituted an interference with its right to freedom of expression. The ECtHR held that widening public access to justice in civil litigation was a legitimate aim, but that the costs obligations imposed on defendants under the CFA regime were disproportionate. The media viewed this judgment as a victory for the reform movement. However, it should be noted that the court appeared to base its decision on the ground that the claimant was a person of considerable wealth and therefore was not at risk of being denied access to justice. ${ }^{6}$

\section{Proposed changes to funding arrangements in the UK (excluding Northern Ireland)}

On 29 March 2011 the government announced that the reforms proposed by Lord Justice Jackson following his comprehensive review ${ }^{7}$ of costs in civil litigation would be implemented in full. Key reforms include lawyers being no longer able to recover success fees and ATE insurance premiums from losing defendants. Any success fees will therefore have to be paid by claimants to their lawyers, although these are capped at 25 per cent of the amount recovered for damages in personal injury cases. A 10 per cent increase in the level of general damages is to be awarded in all civil litigation claims to compensate for the necessity of claimants discharging success fees from damages. CFAs are permitted. For personal injury claims, a "qualified one-way costs shifting" scheme will be implemented. Accordingly, subject to certain exceptions, defendants will not be able to recover costs against an unsuccessful claimant, so as to protect claimants from having to pay excessive costs in the event of an unsuccessful claim. Conversely, defendants will still have to discharge a successful claimant's costs. This reform is based on the premise that in personal injury cases usually the defendant is the party with superior resources. This will not, however, extend to other types of litigation, including defamation.

While Lord Justice Jackson in his original proposal spent some time considering the possibility of reform of the area of costs in defamation claims specifically, ultimately there were no major proposals specifically relating to libel included in the government's proposals for reform by way of implementation of the review recommendations that differed significantly from proposals applicable to civil litigation generally.

Counsel for the Media Lawyers' Association had submitted that the recovery of substantial success fees against unsuccessful defendants in libel cases produced a "gross and

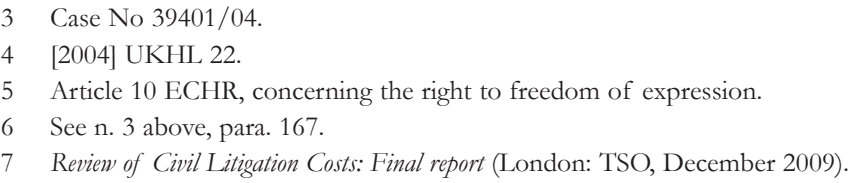


serious interference with freedom of expression". 8 This was countered by claimant groups who argued that any interference was offset by the usual lack of equality of arms in libel cases and the importance of claimants' Article 8 rights (right to respect for private and family life). ${ }^{?}$

The Law Society had submitted for the purpose of the Jackson Review that it did not consider that costs in libel cases should be treated differently to costs in other civil litigation and also opposed costs capping in terms of success fees. ${ }^{10}$ Over the course of the review a working group conducted an assessment of the prospect of introducing a specialised Contingency Legal Aid Fund, although ultimately it concluded that this was not viable. The working group also concluded that the recovery of success fees pursuant to CFA agreements against unsuccessful defendants was unfair, although it was accepted that CFAs and ATE were the only measures that allowed the hypothetical middle-class claimant to feel comfortable in embarking on litigation.

Lord Justice Jackson in his final proposals specific to defamation claims recommended that the level of damages also be increased by 10 per cent. This followed in line with the abolition of recoverability of success fees and ATE premiums, and is intended to enable claimants to pay over a proportion of their damages to their lawyers on successful outcome to their claim. Lord Justice Jackson extended the same proposal for qualified oneway costs shifting as he had made in relation to personal injury and other civil litigation to claims in defamation.

As an additional recommendation for the defamation pre-action protocol in England and Wales, Lord Justice Jackson also recommended that a claimant be required to identify the meaning they attribute to the words complained of in their letter of claim. He also recommended that the question as to whether to retain trial by juries in defamation cases be further considered at some point in the future (given the increased costs of a jury trial as compared to a trial by judge alone).

However, the above reforms will only be applicable to the jurisdiction of England and Wales.

\section{The future}

As previously stated, the fundamental disparity in the position between claimants in Northern Ireland and in the rest of the UK continues, with no indication of any political impetus to implement the funding provisions contained within the Access to Justice (NI) Order 2003. ${ }^{11}$ Indeed, the impending reform in the UK means the order is unlikely to see the light of day any time soon. As a result we are likely to see an ever-decreasing number of libel suits being brought in this jurisdiction, at least by the "man on the street" who is the main victim of this inconsistent approach.

As noted above, the relative advantages currently available to a claimant issuing proceedings in England and Wales are also under threat. The current government reforms to fee arrangements are being pushed through with some considerable determination following what is a relatively limited consultation period.

If these proposals are ultimately implemented they will erode the fundamental right of the ordinary private citizen to access justice (enshrined in Article 6 of the European Convention on Human Rights $)^{12}$ and inhibit their ability to seek vindication of their reputation.

8 Jackson, Review, n. 7 above, para. 2.2.

9 Article 8 ECHR, concerning the right to respect for private and family life, home and correspondence.

10 Review of Civil Litigation Costs: Final report - Response by the Law Society of England and Wales (October 2010).

11 See n. 3 above.

12 Article $6 \mathrm{ECHR}$, concerning the right to a fair and public hearing. 
These reforms are highly disproportionate and go far beyond what is needed to protect freedom of speech, and have had a "chilling effect" on claimants, resulting in a perverse situation where the costs burden is effectively shifted from the wrongdoer to the innocent party. There can be little deterrent for the offending publisher if a successful claimant is required to pay costs out of the damages received for the wrong inflicted upon them.

In both jurisdictions, the complexity of the work and the risks involved mean that lawyers will be increasingly reluctant to take on cases where there is such a financial risk to all concerned.

It appears that in future no matter how damaging the defamatory allegation, or how flagrant the breach of privacy, access to justice will be restricted to the wealthy elite or the extremely courageous. 